\title{
Expression of a dominant-negative Wnt blocks induction of MyoD in Xenopus embryos
}

\author{
Stephan Hoppler, Jeffrey D. Brown, ${ }^{1}$ and Randall T. Moon ${ }^{2}$ \\ Howard Hughes Medical Institute, ${ }^{1}$ Molecular and Cellular Biology Program, and Department of Pharmacology, University \\ of Washington School of Medicine, Seattle, Washington 98195-7750 USA
}

During gastrulation of Xenopus embryos the prospective mesoderm is induced initially with domains of dorsal and ventral fate, then further patterned to generate somitic mesoderm by signals from the gastrula organizer. Although Xwnt-8 is expressed in future ventrolateral mesoderm and induces prospective epidermis to differentiate in vitro as ventral mesoderm, no loss-of-function studies have demonstrated a requirement for Wnt signaling for the normal expression of mesodermal genes in the gastrula. We report development of a dominant-negative Wnt (dnXwnt-8) that inhibits embryonic responses to Wnt signaling in a cellnonautonomous fashion. By expressing dnXwnt-8 in Xenopus embryos, we uncover a requirement of Wnt signaling for localized expression in prospective mesoderm of XMyoDa and Xenopus-posterior (Xpo). Because ectopic expression of functional Xwnt-8 in the dorsal marginal zone of the gastrula induces ectopic XMyoDa and $X p o$, both gain-of-function and loss-of-function experiments support a model in which endogenous $X w n t-8$ functions to induce expression of genes involved in specification of ventral and somitic mesoderm.

[Key Words: Mesoderm; muscle; MyoD; Wnt; Xenopus]

Received June 17, 1996; revised version accepted September 3, 1996.

Wnts are an evolutionary conserved family of secreted proteins that mediate cell-cell signaling (for review, see Nusse and Varmus 1982; Parr and McMahon 1994|. At least two functional classes of Wnt proteins are expressed in Xenopus embryos (Du et al. 1995; Torres et al. 1996), as are homologs of genes described in Drosophila as components of a Wnt signaling pathway (for review, see Yost et al. 1996). In Xenopus embryos, maternal Wnt signaling has been implicated in specification of the embryonic axes (for review, see Cui et al. 1995; Yost et al. 1996), whereas zygotic Wnt signaling pathways may be involved in patterning the ventral mesoderm (Christian and Moon 1993), regulating anteroposterior neural gene expression (McGrew et al. 1995), and modulating morphogenetic movements (Torres et al. 1996).

Several lines of evidence suggest a role for zygotic Xwnt-8 in the patterning of mesoderm in the gastrula (Christian and Moon 1993). First, endogenous Xwnt-8 is expressed primarily in the prospective ventrolateral mesoderm during gastrulation /Christian et al. 1991; Smith and Harland 1991). Second, ectopic expression of Xwnt-8 from a promoter transcribed after the blastula stage diverts the fate of the prospective ectoderm of the animal pole to differentiate in vitro with the histological characteristics of ventral mesoderm. Third, overexpression of $X w n t-8$ from this promoter ventralizes the in vitro dif-

\footnotetext{
${ }^{2}$ Corresponding author.
}

ferentiation of animal pole tissue initially induced by activin to form dorsal mesoderm. Fourth, ectopic expression of $X w n t-8$ in the prospective dorsal mesoderm at the stage when endogenous $X w n t-8$ is expressed diverts the fate of prospective dorsal mesodermal cells to differentiate as more lateral tissue, including somitic muscle (Christian and Moon 1993).

Despite its pattern of expression and activities in gainof-function experiments, it has not heretofore been possible to test whether $X w n t-8$ is actually required for the development of ventral and lateral mesoderm. Here, we describe both loss-of-function and reciprocal gain-offunction experiments that test and confirm the hypothesis that endogenous $X w n t-8$ functions at gastrulation to pattern the prospective tissues of the ventral as well as the lateral mesoderm.

\section{Results}

To test the requirement for Wnt activities in the induction and patterning of mesoderm in the Xenopus gastrula, we designed and tested mutant proteins for their ability to inhibit the responses of Xenopus embryos to Wnt signaling. A mutant allele of Dwnt-1 that encodes a secreted protein with a substantial carboxy-terminal deletion [S84 (Couso and Martinez Arias 1994); amino acid sequence identical to CE7 (Bejsovec and Wieschaus 1995)] was reported to have antimorphic effects in a ge- 
netically sensitized background (Couso and Martinez Arias 1994) (see Fig. 1 for sequence), but in our assays it did not unequivocally antagonize the axis duplicating activity of ectopic $X w n t-8$ (not shown). We then truncated $X w n t-8$ in an attempt to generate a dominant-negative Wnt. Because the site of the S84/CE7 truncation maps to a region not conserved in vertebrate Wnts (Fig. 1 ), we constructed two mutants of Xwnt-8 encoding truncated proteins using a PCR-based method and tested these mutants in the assays described below. One $X w n t-8$ truncation (subsequently referred to as $d n X w n t-$ 8 , see Fig. 1) was found that proved to strongly inhibit embryonic responses to Wnt signaling (see below).

\section{dnXwnt-8 blocks Wnt-induced axis duplication}

When Xwnt-8 RNA is injected into the ventral marginal zone of cleavage-stage Xenopus embryos, ectopic goosecoid ( $g s c$ ) is induced (Fig. 2D) (Christian et al. 1991) and the embryos develop with two axes and heads (Fig. 2C). Strikingly, when both dnXwnt-8 and wildtype $X w n t-8$ RNAs are injected, we find a single domain of gsc expression (Fig. 2F) and embryos that develop with a single embryonic axis (Fig. 2E). dnXwnt-8 RNA is also able to block the axis inducing activity of other Wnt genes with axis duplicating activity, such as Xwnt3A (Wolda et al. 1993), Wnt-1 (McMahon and Moon 1989; Table 1), and Xwnt-8b (Cui et al. 1995; data not shown). However, dnXwnt-8 does not inhibit axis duplication or ectopic gsc expression in response to either a member of the transforming growth factor family, $\mathrm{BVgl}$ (Kessler and Melton 1995) (Table 1), or ectopic $\Delta \beta$-catenin (Fig. 2G,H; Table 1), an active form of $\beta$-catenin that is a known cytoplasmic component of the Wnt signal transduction pathway (Yost et al. 1996). When $d n X w n t-8$ RNA is injected together with RNA encoding Xwnt-5A, a representative of a class of Wnts without axis duplicating activity (for review, see Du et al. 1995), embryos develop with the characteristic phenotype of Xwnt-5Ainjected embryos (not shown). We conclude from these results that $d n X w n t-8$ specifically blocks the activity of members of the functional class of Wnt genes that are able to duplicate the embryonic axis. This inhibition can be overcome with an excess of wild-type Xwnt-8 (Table 2). The inhibition is, however, much stronger if $d n X$ wnt-8 RNA is injected before wild-type Xwnt-8 RNA (Table 2, cf. A and B). Truncation of murine Wnt-1 at an equivalent position also generates a dominant-negative protein able to block the axis-inducing activities of both Wnt-1 and Xwnt-8 (Table 1).

\section{dnXwnt-8 functions in a cell-nonautonomous manner}

To test whether translation of other Wnts is affected by $d n X w n t-8$, we injected RNA encoding Xwnt-8 tagged with a c-myc epitope (Xwnt-8myc; Christian and Moon 1993). Injected Xwnt-8myc RNA is able to duplicate the embryonic axis, an activity that is blocked by $d n X w n t-8$ (not shown, but identical to Fig. 2E,F). Despite the block in axis induction, $d n X w n t-8$ does not affect the expression of Xwnt-8myc protein (Fig. 3, cf. B with A, controls). We conclude that $d n X w n t-8$ blocks embryonic responses to members of the Wnt-1 functional class without interfering with their synthesis.

To test whether dnXwnt-8 functions cell autonomously, we injected RNAs encoding Xwnt-8myc and dnXwnt- 8 in mutually exclusive populations of cells (Fig. 3C,D). We find that $d n X w n t-8$ acts in a cell-nonautonomous manner to block the axis duplicating activity of $X w n t-8 m y c$ and to repress the ectopic induction of gsc in the ventral marginal zone of gastrula embryos (Fig. 3, cf. F, representative of $>50$ embryos assayed, with $\mathrm{E}$,

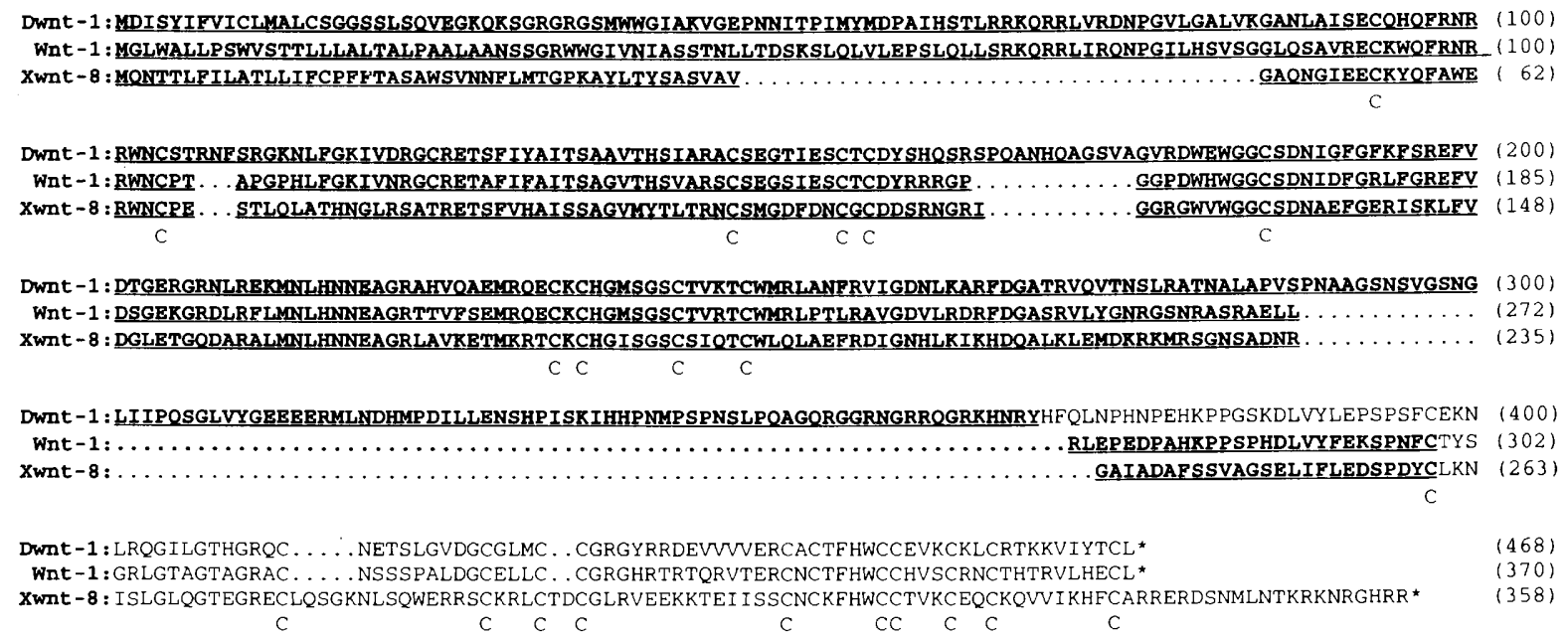

Figure 1. Truncated Wnt protein sequences. Alignment of the amino acid sequences for Dwnt-1 (wingless), mouse Wnt-1, and Xwnt-8. Periods represent gaps in the sequence alignment; the position of conserved cysteine residues are indicated by the letter $C$ below the aligned sequences. The underlined letters represent the sequence of the truncated protein encoded by the $D w n t-1$ mutant alleles $S 84$ and $C E 7$ and the amino acid sequence of dnWnt- 1 and dnXwnt-8, truncated Wnt- 1 and Xwnt- 8 proteins, respectively, with dominant-negative activity. A truncation of Xwnt- 8 at position 230 , which results in a 30 -amino-acid-shorter protein than dnXwnt- 8 , had only weak inhibitory activity. 


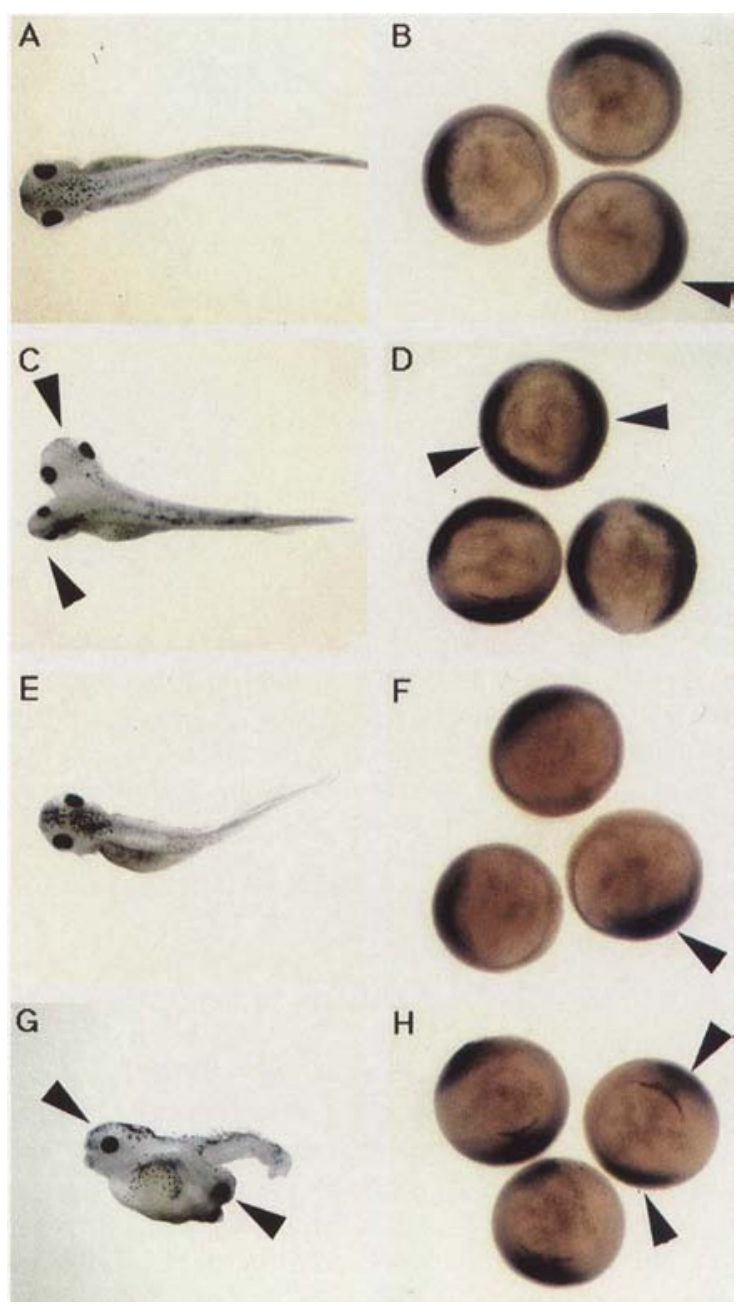

Figure 2. $d n X w n t-8$ inhibits $g s c$ induction and axis duplication by Wnts. Development of tadpoles $(A, C, E, G$, anterior to the left $)$ and $g s c$ in situ hybridization of gastrula-stage embryos $(B, D, F, H)$. Embryos were injected at the four-cell stage with $\sim 300$ pg of control RNA $(A-D)$ or $d n X w n t-8$ RNA $(E-H)$ into each ventral blastomere and again at the 8- to 16-cell stage into the ventral marginal zone with $\sim 25$ pg of RNA encoding Xwnt-8 $(C-F)$ or $\sim 60 \mathrm{pg}$ of $\Delta \beta$-catenin RNA $(G, H)$. The RNA amounts were based on first establishing the lowest amount of each required to elicit a duplication of the axis in most embryos. Embryos injected with control RNA develop with a single head $(A)$ and a single domain of gsc expression $(B$, indicated by arrowhead). When injection of control RNA is followed by a second injection of RNA encoding wild-type Xwnt-8, embryos develop with a duplication of the embryonic axis $(C$, two heads indicated by arrowheads) and with an ectopic domain of gsc expression $(D$, two gsc expression domains indicated by arrowheads). When $d n X w n t-8$ RNA injection precedes that of RNA encoding wild-type Xwnt-8, axis duplication is repressed; embryos develop with one head $(E)$ and with a single domain of $g s c$ expression $(F$, indicated by arrowhead). Injection of $d n X w n t-8$ RNA does not affect the axis duplicating activity of subsequently injected $\Delta \beta$-catenin RNA, and tadpoles develop with two heads $(G$, indicated by arrowheads) and with an ectopic domain of $g s c$ expression $(H$, two $g s c$ expression domains indicated by arrowhead). Note that $d n X w n t-8$ RNA injections specifically inhibit Wnt-induced axis duplication (see also Table 2). controls) suggesting that it interferes with embryonic responses to Wnt signaling following its secretion.

\section{dnXwnt- 8 represses the activity of ectopic Xwnt- 8 expressed later in development}

We then undertook three different experiments to test whether $d n X w n t-8$ could block the activity of Xwnt-8 during later stages of development, when endogenous $X w n t-8$ is expressed (Christian et al. 1991). The first assay was based on expression of $X w n t-8$ in animal pole explants after mid-blastula transition, using a constitutive promoter (CSKA Xwnt-8; Christian and Moon 1993). As shown in Figure 4A, Xwnt-8 expressed in this manner reduces the ability of activin to induce gsc, concomitant with elevating expression of the ventral marginal zone marker, Xpo (X-Xenopus-posterior; Sato and Sargent 1991). Coexpression of $d n X w n t-8$ along with CSKA $X w n t-8$ leads to a pattern of gene expression indistinguishable from that of control animal pole explants treated with activin (Fig. 4A). This assay demonstrates that $d n X w n t-8$ blocks the activity of CSKA Xwnt-8, which expresses $X w n t-8$ at a similar time as the endogenous gene.

The second test exploits the observation that blastula animal pole explants from CSKA $X w n t-8$-injected embryos develop vesicular structures and ventral mesodermal cell types when cultured without exogenous growth factors (Fig. 4, cf. C with B, control explants; Table 3A; Christian and Moon 1993; Cunliffe and Smith 1994). When animal pole explants are injected with both CSKA $X w n t-8$ DNA and $d n X w n t-8$ RNA, the induction of vesicular structures by CSKA $X w n t-8$ is greatly reduced and the explants resemble untreated ones (Fig. 4, cf. D with B, controls; Table 3A).

The third assay relies on the observation that targeting CSKA $X w n t-8$ to the dorsal marginal zone causes development of tadpoles in which dorsoanterior structures are reduced and tissues develop with more lateral fates (Fig. 4F; Christian and Moon 1993). This Wnt-mediated perturbation of development is antagonized by $d n X w n t-8$; embryos injected with both CSKA $X w n t-8$ plasmid and dnXwnt-8 RNA into the dorsal marginal zone develop anterior structures such as cement gland and eyes (Fig. $4 G$; Table $3 \mathrm{~B}$ ). The data from these three independent assays establish that $d n X w n t-8$ RNA antagonizes embryonic responses to ectopic Xwnt-8 expressed after the blastula stage, when the endogenous gene is expressed, and therefore set the stage to perturb endogenous Xwnt signaling.

dnXwnt- 8 reduces the expression of endogenous $\mathrm{XMyoD}$ and other genes in the prospective ventral and somitic mesoderm at early gastrulation

We injected a high dose of $d n X w n t-8$ RNA into the marginal zone of each blastomere of four-cell embryos and analyzed the resulting phenotype of tailbud-stage embryos by morphology (Fig. 5A,B) and histology (Fig. 
Table 1. dnXwnt-8 inhibits Wnt-induced axis duplication

\begin{tabular}{|c|c|c|c|c|c|c|c|c|}
\hline \multicolumn{2}{|c|}{ Ventrally injected RNA } & \multicolumn{4}{|c|}{ Neurula embryonic phenotype } & \multicolumn{3}{|c|}{$g s c$ in $\operatorname{situ}^{\mathrm{b}}$} \\
\hline $\begin{array}{l}\text { four-cell } \\
\text { injection }\end{array}$ & $\begin{array}{c}\text { 16-cell } \\
\text { injection }\end{array}$ & $N$ & $\begin{array}{c}\text { single-axis } \\
|\%|\end{array}$ & $\begin{array}{c}\text { double-axis } \\
|\%|\end{array}$ & $\begin{array}{c}\text { other }^{\mathbf{a}} \\
(\%)\end{array}$ & $N$ & $\begin{array}{c}\text { one gsc } \\
\text { domain }\{\%\rangle\end{array}$ & $\begin{array}{c}\text { two gsc } \\
\text { domains }(\%)\end{array}$ \\
\hline Control & Xwnt-8 & 138 & 8 & 92 & 0 & 33 & 3 & 97 \\
\hline$d n X w n t-8$ & $X w n t-8$ & 123 & 84 & 8 & 8 & 29 & 100 & 0 \\
\hline Control & $X w n t-3 a$ & 40 & 5 & 82 & 13 & N.D. & N.D. & N.D. \\
\hline$d n X w n t-8$ & $X w n t-3 \mathbf{a}$ & 48 & 73 & 6 & 21 & N.D. & N.D. & N.D. \\
\hline Control & $\Delta \beta c a t$ & 81 & 2 & 96 & 2 & 44 & 7 & 93 \\
\hline$d n X w n t-8$ & $\Delta \beta c a t$ & 81 & 6 & 80 & 14 & 77 & 10 & 90 \\
\hline Control & $B V g 1$ & 58 & 16 & 84 & 0 & 32 & 6 & 94 \\
\hline$d n X w n t-8$ & $B V g 1$ & 59 & 3 & 61 & 36 & 33 & 6 & 94 \\
\hline Control & Wnt-1 & 17 & 6 & 94 & 0 & N.D. & N.D. & N.D. \\
\hline$d n W n t-1$ & Wnt-1 & 17 & 100 & 0 & 0 & N.D. & N.D. & N.D. \\
\hline$d n W n t-1$ & Xwnt-8 & 17 & 88 & 12 & 0 & N.D. & N.D. & N.D. \\
\hline
\end{tabular}

Neurula (stage 20| embryos were scored for the development of an ectopic dorsal axis. Gastrula-stage embryos were scored for an ectopic domain of $g s c$ expression, determined by in situ hybridization (an early molecular indication of axis duplication). Embryos were injected at the four-cell stage into the marginal zone of two ventral blastomeres with either control RNA, $d n X w n t-8$ RNA, or $d n W n t-1$ RNA as indicated. At the 16-cell stage, one ventral blastomere was injected with different RNA species encoding proteins that are known to duplicate the embryonic body axis, such as Xwnt-8, Xwnt-3A, $\Delta \beta$-catenin ( $\Delta \beta$ cat), a chimeric protein BMP-4-Vg1 (BVg1), and Wnt-1. Note that both $d n X w n t-8$ and $d n W n t-1$ each inhibit the activity of several members of the Wnt protein family, but that $d n X w n t-8$ does not affect the activity of molecules that are not members of the Wnt family. For details, see Fig. 2.

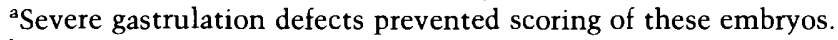

b(N.D.) Not determined.

$5 \mathrm{C}, \mathrm{D} \mid$, and by studying region-specific gene expression in gastrula-stage embryos (Figs. 5E,F and Fig. 6A-D). The morphology of $d n X w n t-8$-injected embryos was found to be clearly abnormal (Fig. 5B, as compared with Fig. 5A, controls|. The embryonic axis is shortened, and the head region appears to be enlarged when compared with the trunk. Most embryos appear to have some minor gastrulation defects, although initiation of gastrulation does not seem to be affected significantly. Histological analysis of cross sections through the trunk region of $23 \mathrm{em}-$ bryos reveals that dorsal mesodermal derivatives such as notochordal tissue are present $(87 \%)$ but that more lateral mesodermal derivatives, such as somitic muscle are reduced or absent $(100 \%)$ (Fig. 5D, as compared with Fig. $5 \mathrm{C}$, representative control embryo). To confirm that dorsal development was not reduced in $d n X w n t-8$-injected embryos, we assayed gene expression of dorsal markers at late blastula-early gastrula stages. $d n X w n t-8$ RNA does not block the expression in the dorsal marginal zone of gsc (Cho et al. 1991; Fig. 5E), noggin (Smith and Harland 1992; data not shown), or Xnr3 (Xenopus nodalrelated; Smith et al. 1995; Fig. 5F).

Histological analysis of cross sections through the trunk region of $d n X w n t-8$-injected embryos (Fig. 5D) was consistent with reduced development of lateral and ventral mesodermal tissues. Staining with a muscle-specific antibody (25 embryos) confirmed that somitic muscle is clearly reduced or absent $(100 \%$; data not shown). This led us to ask whether this phenotype correlated with reduced expression of ventrolateral mesodermal genes in gastrula-stage embryos. We first investigated the expression of Xpo, which is ubiquitously expressed at low levels during blastula stages (Sato and Sargent 1991) and becomes restricted to the ventrolateral marginal zone by the mid-gastrula stage (Amaya et al. 1993). We find that the localized induction of Xpo in the ventrolateral marginal zone (control embryos; Fig. $6 \mathrm{~B}$ ) is blocked in embryos injected with $d n X w n t-8$ RNA and only remnants of the earlier ubiquitous expression is observed (Fig. 6D; see also Table 4A). Injection of $d n X w n t-8$ RNA in only one lateral side of an embryo results in repression of Xpo only in the injected side (data not shown). We then monitored the expression of the Xenopus homeo box gene Evx1 (Ruiz i Altaba and Melton 1989; known previously as Xhox3) by semiquantitative RTPCR on ventral and dorsal halves of gastrula-stage embryos. Whereas control embryos showed a clear enrichment in EVX1 expression in ventral relative to dorsal halves, $d n X w n t-8$ RNA-injected embryos had greatly reduced Evx1 expression in ventral halves /data not shown).

The most interesting effect of $d n X w n t-8$ on expression of endogenous genes came from the analysis of $X M Y O D a$, which encodes a Xenopus homolog of the myogenic transcription factor MyoD (Hopwood et al. 1989; Harvey 1990; Scales et al. 1990). There are several phases of $X M y o D a$ expression in normal embryos. Unlocalized maternal transcripts can be found in oocytes and early embryos (Harvey 1990; Scales et al. 1990). Low-level ubiquitous zygotic expression begins at blastula stage (Rupp and Weintraub 1991), followed by stronger localized expression induced in the lateral but also ventral marginal zone of early gastrula embryos (Frank and Harland 1991). The ventral expression subsequently fades, and $X M Y O D a$ expression becomes restricted to the presumptive somites in the lateral marginal zone of late gastrula stage embryos (e.g., Hopwood et al. 1989; Harvey 1990). Our experiments show that injected 
Table 2. dnXwnt-8 inhibits Xwnt-8-induced axis duplication in a concentration- and time-dependent manner

A.

Injected RNA

Neurula embryonic phenotype

\begin{tabular}{|c|c|c|c|c|c|c|c|c|}
\hline \multicolumn{2}{|c|}{ at two-cell stage } & \multicolumn{2}{|c|}{ at 16 -cell stage } & $N$ & 1 axis $(\%)$ & 1.5 axes $(\%)$ & 2 axes $(\%)$ & dorsalized $(\%)$ \\
\hline Control & $(1000 \mathrm{pg})$ & Xwnt-8 & $(50 \mathrm{pg})$ & 57 & 9 & 16 & 75 & 0 \\
\hline$d n X w n t-8$ & $(1000 \mathrm{pg})$ & Xwnt-8 & $(50 \mathrm{pg})$ & 79 & 99 & 1 & 0 & 0 \\
\hline$d n X w n t-8$ & $(250 \mathrm{pg})$ & $X w n t-8$ & $(50 \mathrm{pg})$ & 86 & 99 & 1 & 0 & 0 \\
\hline$d n X w n t-8$ & $(50 \mathrm{pg})$ & $X w n t-8$ & (50 pg) & 108 & 92 & 8 & 0 & 0 \\
\hline$d n X w n t-8$ & $(50 \mathrm{pg})$ & Xwnt-8 & $(250 \mathrm{pg})$ & 113 & 27 & 26 & 13 & 34 \\
\hline$d n X w n t-8$ & $(50 \mathrm{pg})$ & Xwnt-8 & (1000 pg) & 63 & 3 & 5 & 2 & 90 \\
\hline
\end{tabular}

B.

\begin{tabular}{|c|c|c|c|c|c|c|c|c|}
\hline \multicolumn{4}{|c|}{ Injected RNA } & \multicolumn{5}{|c|}{ Neurula embryonic phenotype } \\
\hline \multicolumn{2}{|c|}{ at four-cell stage } & \multicolumn{2}{|c|}{ at four-cell stage } & $N$ & 1 axis $(\%)$ & 1.5 axes $(\%)$ & 2 axes $(\%)$ & dorsalized $(\%)$ \\
\hline Control & $(250 \mathrm{pg})$ & $X w n t-8$ & $(50 \mathrm{pg})$ & 94 & 0 & 0 & 100 & 0 \\
\hline$d n X w n t-8$ & $(1000 \mathrm{pg})$ & $X w n t-8$ & $(50 \mathrm{pg})$ & 49 & 100 & 0 & 0 & 0 \\
\hline$d n X w n t-8$ & $(250 \mathrm{pg})$ & $X w n t-8$ & $(50 \mathrm{pg})$ & 84 & 39 & 61 & 0 & 0 \\
\hline$d n X w n t-8$ & $(50 \mathrm{pg})$ & Xwnt -8 & $(50 \mathrm{pg})$ & 96 & 0 & 0 & 100 & 0 \\
\hline
\end{tabular}

Late neurula (stage 22) embryos were scored for the development of an ectopic axis. 1.5 axes indicates embryos whose ectopic axis does not form a cement gland.

(A) Embryos were first injected at the two-cell stage into the ventral marginal zone with different amounts of $d n X w n t-8$ RNA (as indicated) and then at the 16-cell stage into two ventral marginal blastomeres with different amounts of Xwnt-8 RNA (as indicated). Note that with this injection protocol $d n X w n t-8$ RNA almost completely represses the activity of equal amounts of $X w n t-8$ RNA and that the inhibitory effect of $d n X w n t-8$ can be overridden only with a large excess of Xwnt- 8 RNA.

$(B)$ Embryos were injected at the four-cell stage into the ventral marginal zone with different amounts of $d n X w n t-8$ RNA (as indicated) and with different amounts of $X w n t-8$ RNA (as indicated). Note that with this injection protocol $d n X w n t-8$ RNA cannot repress the activity of equal amounts of Xwnt-8 RNA but that a large excess of $d n X w n t-8$ can repress the activity of $X w n t-8$.

dnXwnt-8 RNA represses both phases of localized $X M y o D a$ expression in the marginal zone of gastrula stage embryos (Fig. 6, cf. C with A, controls; see also Table 4A). Injection of $d n X w n t-8$ RNA in only half of an embryo represses $X M y o D a$ expression only on the injected side (data not shown).

Because endogenous $X w n t-8$ is expressed in the lateral and ventral prospective mesoderm (Christian et al. 1991; Smith and Harland 1991), it appears likely that dnXwnt-8 RNA injections block the function of this gene. To further establish that Xwnt- 8 functions in the lateral and ventral marginal zone to induce the expression of $X p o$ and $X M y o D a$, we sought to override the inhibition of Wnt signaling by overexpressing wild-type $X w n t-8$ in ventrolateral cells of embryos injected previously with $d n X w n t-8$ RNA. The expression of both Xpo (Fig. 6F) and $X M Y O D a$ (Fig. 6E) could be rescued by injecting CSKA Xwnt-8 DNA into one ventrovegetal blastomere of eight-cell embryos, whereas injection of control DNA at the same concentration was not able to enhance the expression of these genes (not shown, but identical to Fig. $6 \mathrm{C}, \mathrm{D}$; see also Table 4B).

Ectopic Xwnt-8 induces ectopic expression of XMyoD and Xpo, marker genes for prospective ventral and somitic mesodermal tissue at early gastrulation

Because expression of XMyoDa and Xpo in the prospective ventral and lateral mesoderm is dependent on Wnt signaling, the restriction of endogenous Xwnt-8 expression to the ventrolateral marginal zone during gastrulation might be sufficient to explain the lack of expression of these genes in the dorsal marginal zone. To test this hypothesis, we targeted CSKA Xwnt-8 DNA to the dorsal or ventral marginal zone of the gastrula as in Christian and Moon (1993) and monitored the expression of $X M y o D a$ and $X p o$ transcripts. In uninjected embryos there is a gap of expression of both genes on the dorsal side above the dorsal lip. In the case of $X M Y O D a$ this dorsal exclusion is very pronounced (Fig. 6A,G; see also Table $4 \mathrm{C}$ ), whereas the dorsal gap in Xpo expression is more diffuse (Fig. 6B,H; see also Table $4 \mathrm{C}$ ). When CSKA $X w n t-8$ is targeted to the dorsal marginal zone, the domain of expression of XMyoDa (Fig. 6I; Table 4C) and $X p o$ (Fig. 6J; Table 4C) now includes the dorsal marginal zone. These data demonstrate that Wnt signaling is not only required for the expression of these genes (see above loss-of-function analyses), but that $X w n t-8$ is also sufficient in the marginal zone for expression of these genes.

\section{Discussion}

The requirement of Wnt signaling for ventrolateral mesoderm

Intercellular signaling has long been implicated in the establishment of cell fate within different regions of the 
Figure 3. $d n X w n t-8$ blocks embryonic responses to $X w n t-8$ in a cell nonautonomous manner. $(A, B)$ Embryos were first injected at the four-cell stage with either $\sim 300 \mathrm{pg}$ of control RNA $\langle A|$ or $d n X w n t-8$ RNA $(B)$ into the marginal zone of both ventral blastomeres and again at the 16-cell stage $(A, B)$ into a single ventral marginal blastomere with $\sim 50 \mathrm{pg}$ of $X w n t$ $8 m y c$ RNA. At gastrula stage 10, embryos were fixed and stained for expression of the c-myc epitope (dark brown staining), which revealed that $d n X w n t-8$ does not affect the expression of $X$ wnt-8myc (cf. $B$ with $A$, control), although it blocks its axis-duplicating activity (not shown, but identical to Fig. 2E,F). (C) Drawing (Nieuwkoop and Faber 1967) explaining the design of the nonautonomy experiment in $D-F$, with five cells (red hatched) being injected at the early 16-cell stage (indicated by arrows) with lineage tracer (phenol red and $\beta$-galactosidase RNA) and $\sim 250$ pg of RNAs (either $d n X w n t-8$ RNA or a control RNA). Then, at the late 16-cell stage the central cell [white cell within the red hatched area indicated by an asterisk (*)| was injected with $\sim 25$ pg of $X$ wnt-8myc RNA. $(D)$ Blastulastage embryos injected as in $C$ were processed for $\beta$-galactosidase activity (blue) and $c$-myc epitope localization (light brown). Note that the blue $\beta$-galactosidase RNA-injected cells (indicated by arrowhead) do not overlap with the brown $X w n t-8 m y c$ RNA-injected cells [indicated by an asterisk $\left({ }^{*}\right)$. (E) An endogenous and an ectopic domain of $g s c$ expression (solid arrowheads) are evident when control RNAs are injected into the five red cells as in $C$, followed by $X w n t-8 m y c$ in the central cell. $|F|$ In contrast, injection of $d n X w n t-8$ into the five red cells as in $C$, followed by $X w n t-8 m y c$ into the central cell, had greatly reduced or no ectopic gsc expression (the shaded arrowhead indicates an ectopic domain of reduced gsc expression in the embryo at right). Note that $d n X w n t-8$ is able to block the induction of gsc (cf. $F$ with $E$, control), even if the proteins are expressed in exclusive populations of cells, as shown with the complementary staining in $D$.

Xenopus embryo (e.g., Nieuwkoop 1969). Recent studies have begun to identify candidate signal transduction pathways that may be operative and required during embryonic induction. Focusing on the formation of ventral mesoderm, both BMP-4 (e.g., Dale et al. 1992; Fainsod et al. 1994; Graff et al. 1994; Schmidt et al. 1995; Steinbeisser et al. 1995) and zygotic Xwnt-8 (Christian and Moon 1993) have been identified as candidate secreted factors involved in the induction and patterning of this region of the embryo.

Several new lines of evidence from the present study further implicate $X w n t-8$ in specifying ventral and lateral mesoderm. We have shown that expressing $d n$ $X w n t-8$ in regions that also express endogenous Xwnt-8 reduces the development of somitic muscle and inhibits the expression at gastrula stage of the ventral and lateral genes Xpo (Sato and Sargent 1991; Amaya et al. 1993), Xenopus homeo box gene Evx1 (Ruiz i Altaba and Melton 1989), and XMyoDa (Hopwood et al. 1989). Conversely, we have shown that ectopic expression of functional $X w n t-8$ in the dorsal marginal zone of the gastrula induces ectopic expression of both $X M y o D a$ and $X p o$, concomitant with diverting the fate of this dorsal region to more lateral fates including skeletal muscle /Christian and Moon 1993). Taken with the observation that expression of Xwnt-8 is normally highly enriched in the ventrolateral prospective mesoderm (Christian et al. 1991; Smith and Harland 1991), these new loss-of-function and gain-of-function data establish a role of endogenous $X w n t-8$ in the induction of genes likely to be involved in regulating ventrolateral mesodermal fate.

There are some noticeable parallels between functions of BMP-4 and Xwnt-8. Endogenous expression of both genes in the marginal zone of gastrula stage embryos is excluded from the dorsal side (Christian et al. 1991; Smith and Harland 1991; Fainsod et al. 1994; Schmidt et al. 1995). Furthermore, ectopic expression of Xwnt-8 (from CSKA $X w n t-8$ plasmid) in the dorsal marginal zone of gastrula-stage embryos results in development of embryos with similar phenotypes as those in which BMP-4 is ectopically expressed. However, there are also some crucial differences between $X w n t-8$ and $B M P-4$. First, $X w n t-8$ expression in the ventrolateral marginal zone is induced in response to mesoderm induction /Christian et al. 1991; Christian and Moon 1993); BMP-4, on the other hand, is expressed in uninduced tissue (Dale et al. 1992; Fainsod et al. 1994; Schmidt et al. 1995). Second, unlike BMP-4 (e.g., Dale et al. 1992; Schmidt et al. 1995), ec- 


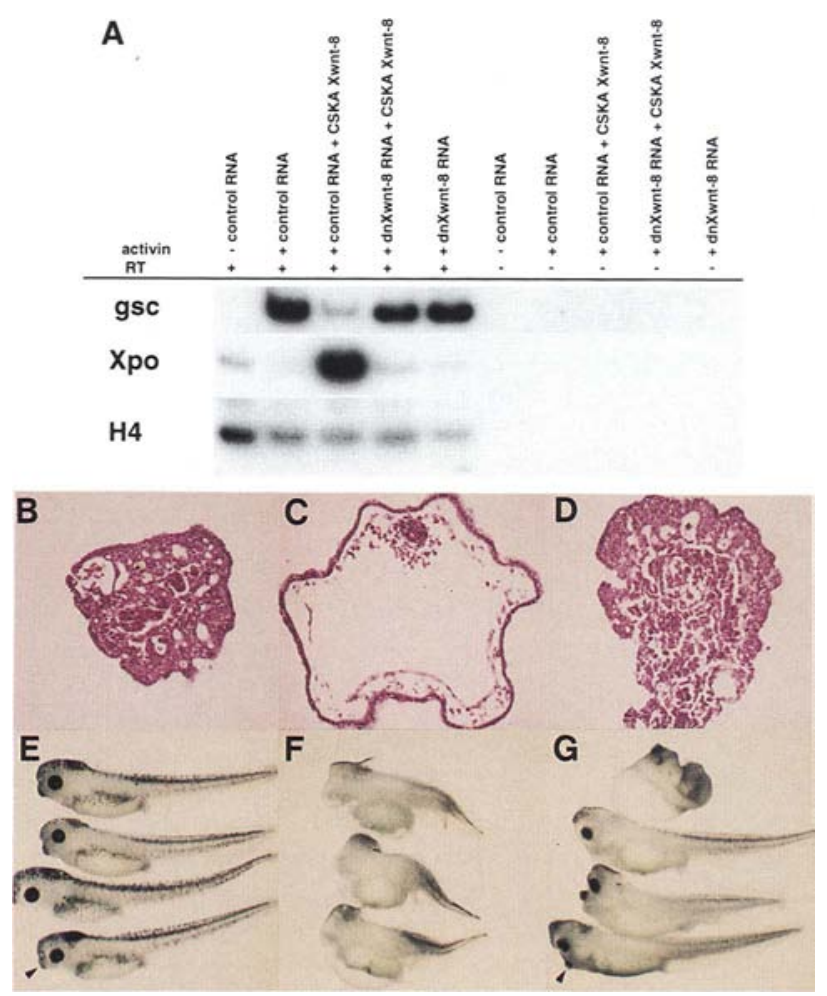

Figure 4. $d n X w n t-8$ inhibits $X w n t-8$ expressed after the blastula stage. (A) RT-PCR analysis of gene expression in control stage 12 animal explants for a control marker (histone H4), a dorsal marginal zone marker $(g s c)$, and a ventral marginal zone marker (Xpo). Embryos were injected at the two-cell stage into the animal pole of both blastomeres with $\sim 800 \mathrm{pg}$ of control RNA or dnXwnt-8 RNA (as indicated at top) and $\sim 80 \mathrm{pg}$ of CSKA Xwnt-8 plasmid DNA (where indicated at top), and animal caps were explanted and treated with activin (where indicated by +$)$ and subjected to analysis with RT-PCR. $(B-D)$ Histological sections through animal pole explants. Embryos were injected at the two-cell stage into the animal pole of both blastomeres with $\sim 200 \mathrm{pg}$ of control RNA (B), with $\sim 200$ pg of control RNA, and $\sim 30 \mathrm{pg}$ of CSKA $X w n t-8$ plasmid $(C)$, or $\sim 200$ pg of $d n X w n t-8$ RNA and $\sim 30$ pg of CSKA $X w n t-8$ plasmid (D). Animal pole explants were prepared at stage 8 , then cultured until sibling embryos reached stages $38-40$. Note that dnXwnt-8 RNA represses the formation of vesicular structures induced by CSKA Xwnt-8 (see Table 3A). (E-G) Stage 40 embryos (anterior to the left and dorsal on the top) that developed from embryos injected at the four-cell stage into the marginal zone of both dorsal blastomeres with $\sim 200 \mathrm{pg}$ of control RNA $(E), \sim 200 \mathrm{pg}$ of control RNA mixed with $\sim 30 \mathrm{pg}$ of CSKA $X w n t-8$ plasmid $\{F\rangle$, or $\sim 200$ pg of $d n X w n t-8$ RNA mixed with $\sim 30$ pg of CSKA Xwnt-8 plasmid $(G)$. Note that $d n X w n t-8$ interferes with the $X w n t-8$-mediated repression of dorsoanterior structures such as cement gland (indicated by small arrowheads) and eyes (see also Table 3B).

topic expression of $X w n t-8$ (from CSKA $X w n t-8$ plasmid) in the dorsal marginal zone does not repress expression of gsc (Christian and Moon 1993). Third, we have shown here that repression of Wnt signaling does not result in ectopic expression of dorsal marginal markers, unlike repression of BMP signaling (e.g., Graff et al. 1994; Schmidt et al. 1995; Steinbeisser et al. 1995).

$X w n t-8$ is not expected to be sufficient for inducing $X M y o D a$ in the prospective somitic mesoderm of gastrula-stage embryos, because the expression pattern of the two genes are not identical at this stage /Christian et al. 1991; Frank and Harland 1991; Smith and Harland 1991). Although XMyoDa expression stays well within the putative signaling range of Xwnt-8-expressing cells, the wedge-like concentration gradient of $M y o D$ transcripts (the more dorsal the higher) in the lateral marginal zone of gastrula-stage embryos suggests a promoting influence from the dorsal mesoderm. Dorsal marginal tissue has indeed been shown to be required for somitic development (Stewart and Gerhart 1990). A likely candidate for a dorsal signal promoting $X M y o D$ expression is the secreted protein noggin, which if added to prospective ventral tissue induces muscle development and muscle-specific gene expression (Smith et al. 1993). On the other hand, there is recent evidence from other vertebrates that signaling factors of the hedgehog class are involved in the patterning of somites (Fan and Tessier Lavigne 1994) and in regulating MyoD expression (Hammerschmidt et al. 1996; Weinberg et al. 1996). Moreover, hedgehog signals were found to act in combination with Wnt molecules in vitro to induce myogenic gene expression (Münsterberg et al. 1995).

All three ventrolateral genes examined in this study encode putative transcription factors; $X p o$ encodes a protein with a zinc finger domain of the type CCHC /Sato and Sargent 1991), Evx1 encodes a homeo domain containing protein, and $M y O D$ encodes a transcription factor with a basic-helix-loop-helix DNA-binding domain (Murre et al. 1989; Benezra et al. 1990). These factors may regulate the expression of structural genes that form the differentiated tissues observed at later stages. In $X e$ nopus the expression of $X M Y O D$ from mid-gastrulation stage onwards outlines the presumptive somites, which develop into the major muscle masses of the body, raising the question as to whether it is an important regulator of myogenesis. Because injection of CSKA Xwnt-8 into the prospective dorsal mesoderm induces $X M y O D a$ (this paper) and causes the development of ectopic somitic muscle (Christian and Moon 1993) and because $X M y o D$ is sufficient to induce some muscle genes (Hopwood and Gurdon 1990), it is likely that XMyoD is an important regulator of myogenesis in Xenopus. However, mice lacking $M y o D$ develop skeletal muscles (Rudnicki et al. 1992), and consistent with this, we find that embryos injected with dnXwnt-8 RNA develop at least some somitic tissue despite the repression of $X M y o D a$.

We are intrigued by the possibility that the role of $X w n t-8$ somite formation and myogenesis in Xenopus may be conserved in vertebrate development. Closely related Wnt molecules are expressed in zebrafish (wnt8; Kelly et al. 1995), as well as chick and rat (Cwnt-8C and Rwnt-8C; Hume and Dodd 1993), in similar patterns at comparable developmental stages. Moreover, somitic muscle formation has recently been found to be induced 
Table 3. dnXwnt- 8 inhibits activity of Xwnt- 8 expressed after the blastula stage

\begin{tabular}{|c|c|c|c|c|c|c|c|c|c|c|}
\hline $\begin{array}{l}\text { A. } \\
\text { Injected molecules }\end{array}$ & $N$ & $\begin{array}{l}\text { Epidermis } \\
(\%)\end{array}$ & $\begin{array}{l}\text { Small } \\
\text { vesicles }(\%)\end{array}$ & $\begin{array}{l}\text { Large } \\
\text { vesicles }(\%)\end{array}$ & $\begin{array}{l}\text { Meso } \\
(\%)\end{array}$ & lium & $\begin{array}{l}\text { Mese } \\
(\%)\end{array}$ & yme & $\begin{array}{l}\text { Eryt } \\
(\%)\end{array}$ & Irocytes \\
\hline Control RNA & 33 & 79 & 21 & 0 & & & & & & 0 \\
\hline Control RNA + CSKA X8 DNA & 56 & 20 & 48 & 32 & & & & & & 18 \\
\hline$d n X w n t-8$ RNA + CSKA X8 DNA & 41 & 54 & 46 & 0 & & & & & & 7 \\
\hline $\begin{array}{l}\text { B. } \\
\text { Injected molecules }\end{array}$ & $N$ & $\begin{array}{l}\text { Normal } \\
(\%)\end{array}$ & $\begin{array}{l}\text { Small CG } \\
\text { eyes } \\
\text { normal }(\%)\end{array}$ & $\begin{array}{l}\text { Small C } \\
\text { eyes } \\
\text { abnorm }\end{array}$ & $\begin{array}{l}\mathrm{G}, \\
\mathrm{l}(\%)\end{array}$ & $\begin{array}{l}\text { No C } \\
\text { eyes } \\
\text { cyclo }\end{array}$ & ic $(\%)$ & $\begin{array}{l}\text { No } C \\
\text { no e } \\
(\%)\end{array}$ & & $\begin{array}{l}\text { Other } \\
(\%)\end{array}$ \\
\hline RNA & 16 & 100 & 0 & 0 & & & 0 & c & P & 0 \\
\hline Control RNA + CSKA X8 DNA & 28 & 4 & 0 & 0 & & & 36 & 60 & & 0 \\
\hline$d n X w n t-8$ RNA + CSKA X8 DNA & 27 & 22 & 19 & 26 & & & 33 & c & 0 & 37 \\
\hline
\end{tabular}

(A) Histological sections of animal explants cultured until sibling control embryos reached stage 36-40 and scored for differentiation of putative epidermal tissue $\mid<10 \%$ vesicular structures per area), tissue with small vesicles (between $10 \%$ and $50 \%$ vesicular structure per area) or putative ventral mesodermal tissue with large vesicles $(50 \%$ and more vesicular structure per area). These sections were also scored for the appearance of cell types resembling those typical for ventral mesodermal tissue. Two-cell embryos were injected into the animal pole with a mixture of control RNA or $d n X w n t-8$ RNA (as indicated) and plasmid DNA encoding Xwnt-8 (CSKA X8). $N$ represents the number of animal caps; for each animal cap several sections were examined. Note that Xwnt- 8 induces vesicular structures and leads to the development of putative ventral mesodermal cell types, whereas dnXwnt- 8 inhibits this activity. See Fig. 4 for representative explants.

(B) Tailbud stage embryos ( stage 40) were scored for the development of anterior structures, such as eyes and cement gland (CG). Embryos were injected at the four-cell stage into the marginal zone of both dorsal blastomeres with either control RNA or $d n X w n t-8$ RNA (as indicated) mixed with CSKA Xwnt-8 plasmid DNA (CSKA X8). The term "normal" designates embryos with relatively normal development of the head region. A large proportion of the $d n X w n t-8$-injected embryos developed with relatively normal development of the head region. A large proportion of the $d n X w n t-8$-injected embryos developed other phenotypes ("other"), such as apparently shortened axis (see Figs. 4F and 5B), which did not affect the development or scoring of anterior structures. See Fig. 4 for representative embryos.

in vitro by Wnt signaling in chick (Münsterberg et al. 1995; Stern et al. 1995). The developmental role of Wnt signaling in muscle formation may even be conserved beyond vertebrates; Dwnt-1 is both required and sufficient for the formation of a subset of muscle founder cells in Drosophila melanogaster (Baylies et al. 1995).

Injection of RNA encoding members of the Wnt-1
Figure 5. dnXwnt-8-injected embryos develop dorsal mesoderm but form defective somites. $(A, C)$ Injection of $\sim 3 \mathrm{ng}$ of control RNA into cleavage-stage embryos leads to development of normal stage 36-38 embryos, both in terms of external morphology $(A$, anterior to left, dorsal on top) and internal anatomy, as examined in histological cross section through the trunk region $\{C$, dorsal on top $\rangle .(B, D)$ When $1.5-3 \mathrm{ng}$ of $d n X w n t-8$ RNA is injected, development is highly aberrant, embryos develop with a shortened axis as well as a relatively enlarged head region $(B)$, and histological cross section through such embryos $(D)$ reveals that the notochord is enlarged and that somitic muscle tissue is reduced and disorganized. (E) Injection into the marginal zone of all four blastomeres of four-cell embryos with $1.5-3 \mathrm{ng}$ of RNAs encoding either control protein (bottom) or $d n X w n t-8$ (top) results in normal expression of gsc. (F) Similarly, $1.5-3 \mathrm{ng}$ of $d n X w n t-8$ (top) does not significantly reduce the level of expression of Xnr3 compared with control embryos (bottom). (en) Endoderm; (no) notochord (nt) neural tube; (sm) somitic muscle.

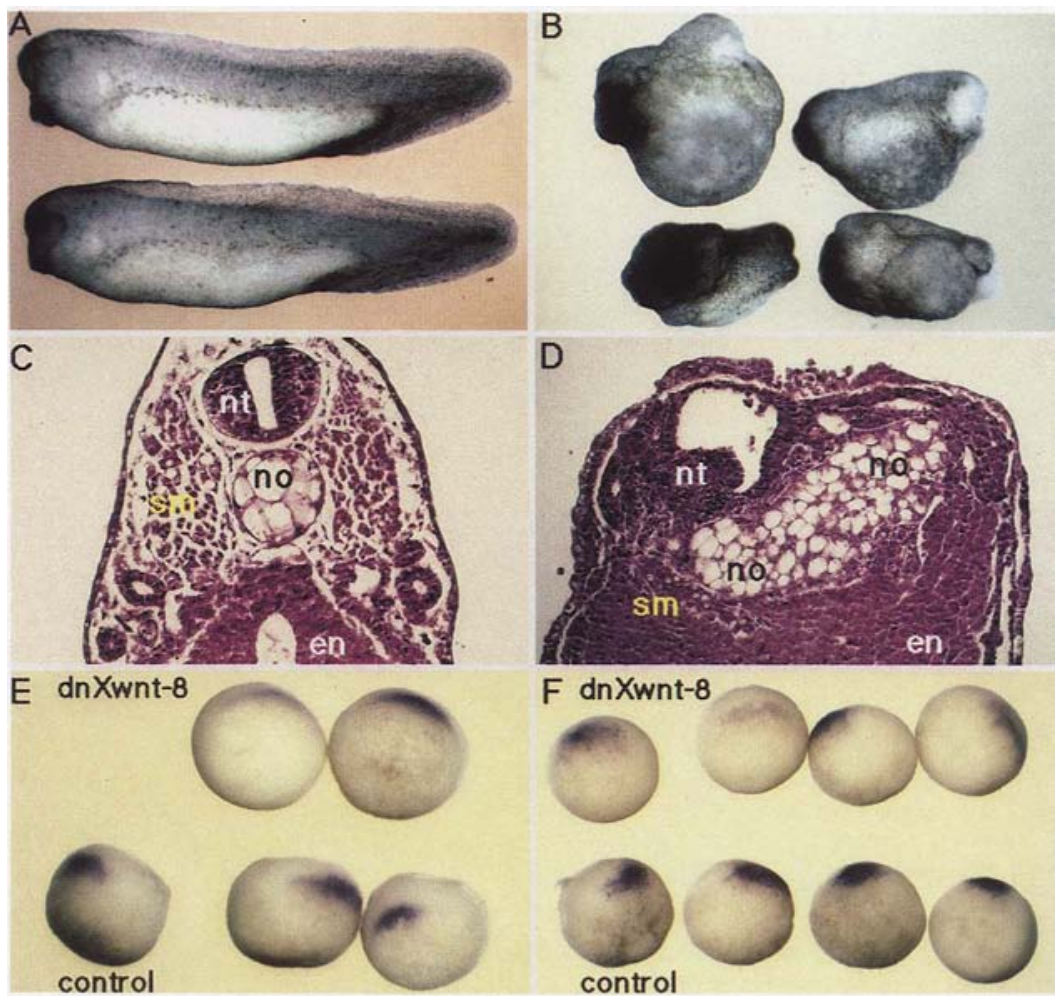



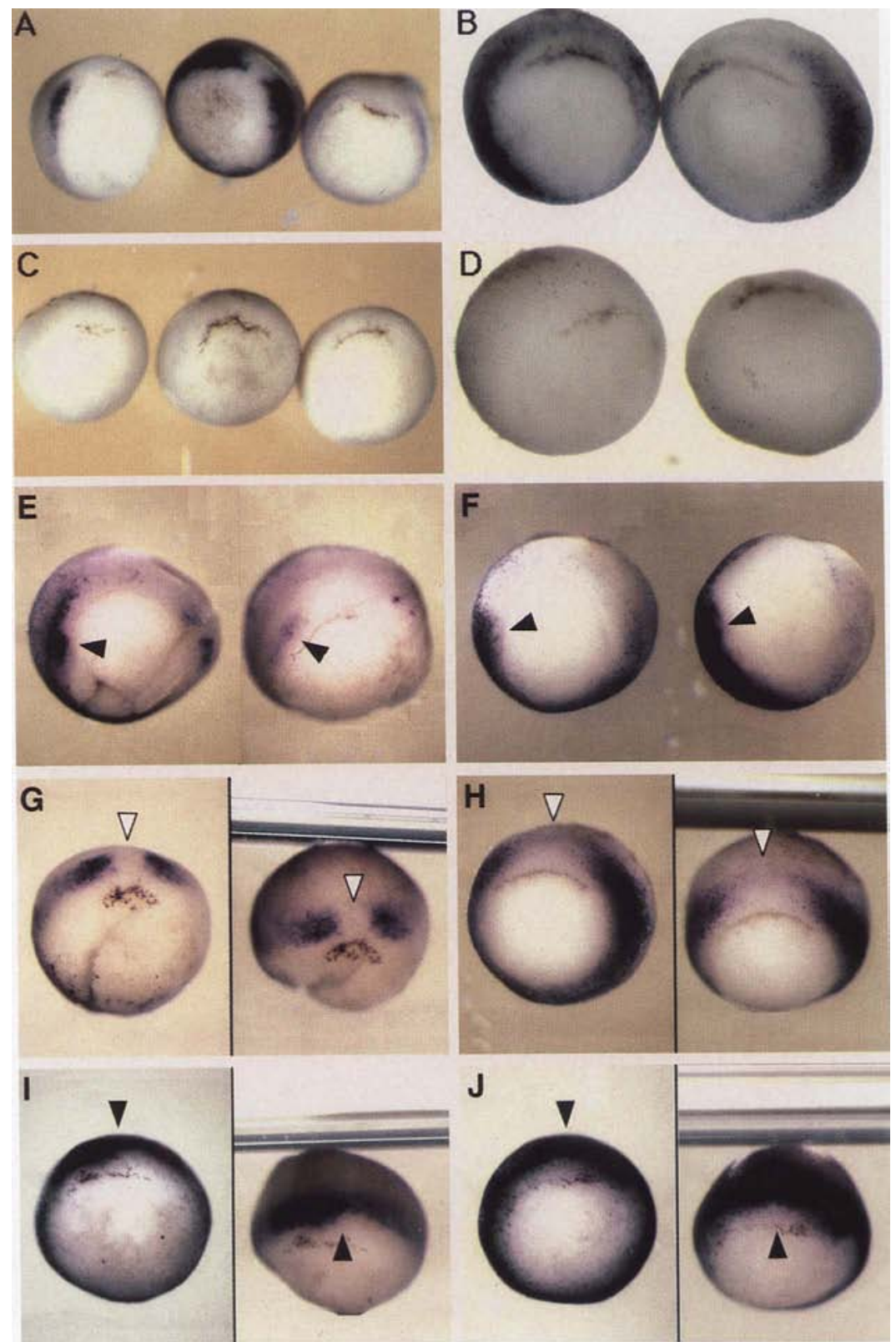

Figure 6. $d n X w n t-8$ blocks induction of $X M y o D a$ and $X p o$ in the ventral and lateral marginal zone, whereas ectopic $X$ wnt- 8 induces ectopic expression of these markers in the dorsal marginal zone. In situ hybridization (purple staining) of stage $101 / 4-10 \frac{1}{2}$ embryos with probes for $X M y o D a(A, C, E, G, I)$ and $X p o$ $(B, D, F, H, J) .(A, B)$ Control RNA $(\sim 3 \mathrm{ng})$ injections into the marginal zone of all four blastomeres of four-cell embryos lead to normal expression of both the lateral mesodermal marker $X M y o D a\langle A|$ and the ventrolateral mesodermal marker $X p o(B) .(C, D)$ When $0.8-3$ pg of $d n X w n t-8$ RNA is injected, expression of $X M y O D a$ is abolished $(C)$ and localized $X p o$ RNA staining is greatly reduced $(D)$ (see Table 4A). $(E, F)$ Overexpression of wild-type $X w n t-8$ (CSKA Xwnt-8, $\sim 100 \mathrm{pg}$ ) in one side of the ventrolateral mesoderm of $d n X w n t-8$ RNA $1 \sim 800$ $\mathrm{pg}$ )-injected embryos rescues the expression of the mesodermal markers $X M y o D a(E$, indicated by arrowheads $)$ and $X p o(F$, indicated by arrowheads) predominantly on the side of injection (see also Table 4B). (G-I) In a gain-of-function analysis, CSKA $X w n t-8$ DNA $(\sim 100 \mathrm{pg})$ was injected into the marginal zone of both dorsal blastomeres at the four-cell stage $(I, J)$ to ectopically express $X w n t-8$ in the dorsal prospective mesoderm. Whereas ventral injected embryos have the normal dorsal gap of $X M y O D a$ expression $[G$, indicated by an open arrowhead; vegetal view (left) and dorsal view (right) of the same embryo; see Table $4 \mathrm{C}$, ectopic Xwnt-8 expression results in the ectopic expression of $X M y o D a$ in most dorsal prospective mesoderm $[I$, indicated by a solid arrowhead; vegetal view (left) and dorsal view (right) of the same embryo]. Similarly, whereas uninjected embryos show only weak $X p o$ staining on the dorsal side $[H$, indicated by an open arrowhead; vegetal view (left) and dorsal view (right) of the same embryo; see also Table 4C], ectopic $X w n t-8$ expression also causes strong expression of $X p O$ in the dorsal prospective mesoderm $[J$, indicated by a solid arrowhead, vegetal view (left) and dorsal view (right) of the same embryo]. functional class promotes the formation of an ectopic axis (for review, see McMahon and Moon 1989; Du et al. 1995), an activity that we find can be blocked by $d n X w n t-8$. However, blocking Wnt signaling by injecting $d n X w n t-8$ RNA into the marginal zone of early $X e$ nopus embryos does not abolish all aspects of the endogenous axis; though they are severely malformed, these embryos develop dorsal structures as determined by morphology and histology and the expression of dorsal mesodermal genes is not blocked. These results suggest that Wnts may not be required for establishing dorsal mesoderm. However, other data still support the involvement of the Wnt signaling pathway in specifying the dorsal axis. Specifically, $\beta$-catenin, a cytoplasmic component of the Wnt signaling pathway, has been found to be required for axis formation (Heasman et al. 1994), and it can be regulated post-translationally by GSK-3 in early embryos (Yost et al. 1996). Given this requirement for $\beta$-catenin, its likely regulation by endogenous GSK-3, and the lack of effect of the $d n X w n t-8$ on the formation of the endogenous axis, it is conceivable that formation of the endogenous axis requires cytoplasmic components of the Wnt pathway but not a Wnt ligand.

\section{A dominant-negative Wnt protein}

By deleting a particular carboxy-terminal fragment of Xwnt-8, we generated dnXwnt-8, which blocks embry- 
Table 4. dnXwnt-8 inhibits induction of XMyoD and Xpo expression

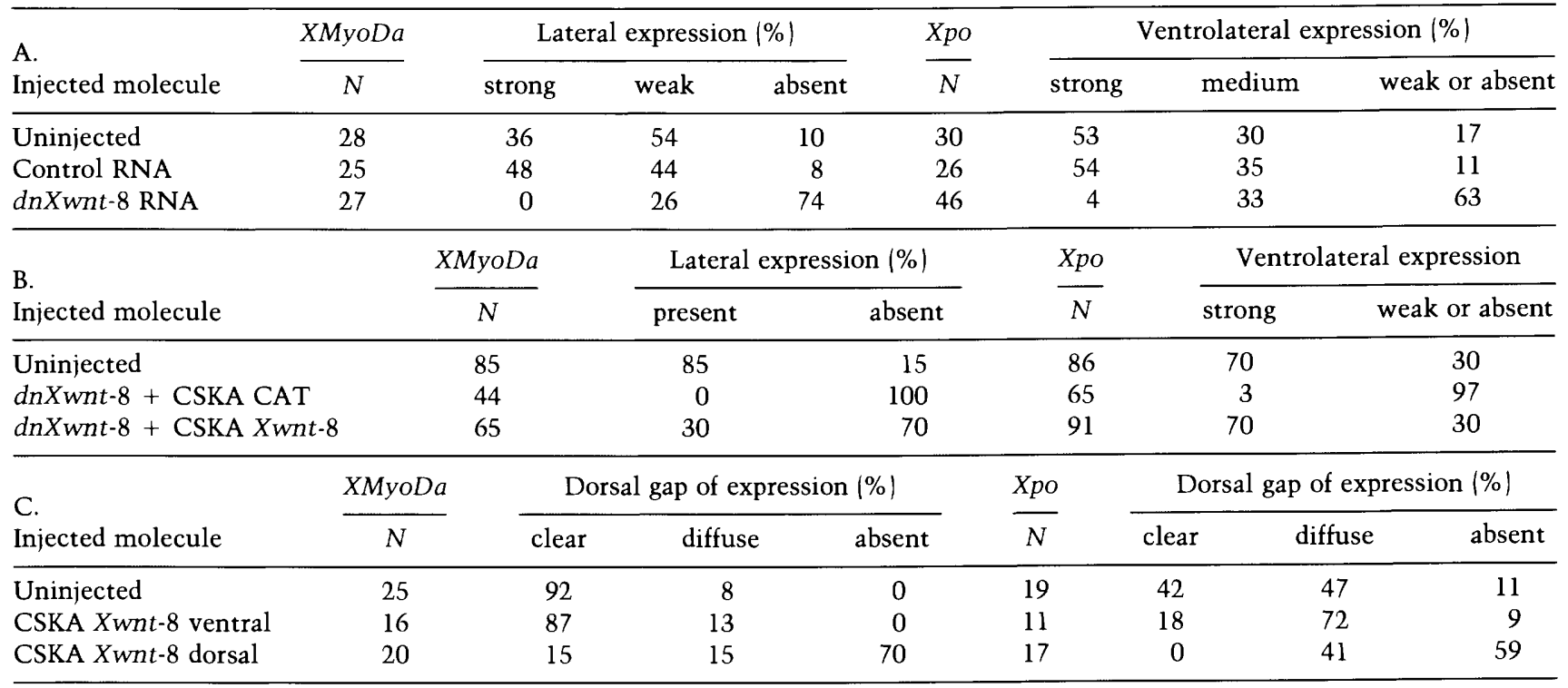

(A) Expression of the lateral and ventral marginal markers $X M Y O D a$ and $X p o$ in gastrulation stage (stage 101/4-101/2) embryos as determined by in situ hybridization. Embryos were injected at the four-cell stage into the marginal zone of all four blastomeres. Note that $d n X w n t-8$ inhibits the localized gene expression of both $X M y o D a$ and $X p o$. Wnt signaling is therefore required for localized expression of these two genes. See Fig. 6A-D for representative embryos.

(B) Expression of the lateral and ventral marginal markers XMyoDa and Xpo in gastrulation stage (stage 101/4-101/2) embryos as determined by in situ hybridization. Embryos were first injected with $d n X w n t-8$ RNA at the four-cell stage into the marginal zone of all four blastomeres and then with the DNA species indicated at the eight-cell stage into one ventrovegetal blastomere. Note that overexpression of Xwnt-8 rescues the expression of both XMyoDa and Xpo in $d n X w n t-8$-injected embryos. See Fig. 6E, F for representative embryos.

(C) Absence or presence of expression in the most dorsal marginal zone ("dorsal gap of expression") of the lateral and ventral marginal markers $X M y o D a$ and $X p o$ in gastrulation stage (stage 101/4-101/2 embryos as determined by in situ hybridization. Embryos were injected with CSKA $X$ wnt -8 plasmid DNA at the four-cell stage into the dorsal marginal zone of the two dorsal blastomeres or into the ventral marginal zone of the two ventral blastomeres (as indicated). Note that dorsal $X w n t-8$ expression causes XMyoD and Xpo to be expressed ectopically in the dorsal marginal zone. Xwnt- 8 is therefore sufficient for the expression of these marker genes in marginal zone tissue. See Fig. 6G, $\mathrm{H}$ for representative embryo.

onic responses to Wnt signaling in a dominant-negative manner. We introduced the same deletion into mouse Wnt-1 (dnWnt-1) and found that it also blocks responses to Wnts. We find that the inhibition caused by dnXwnt- 8 can be overridden in two different assays by providing an excess of Xwnt-8. Although we do not know how dominant-negative Wnts interfere with embryonic responses to Wnts, we have established that dnXwnt- 8 functions cell nonautonomously. Because we have also established that dnXwnt- 8 does not inhibit the signaling activity of ectopic $\beta$-catenin, a cytoplasmic component of the Wnt signaling pathway (for review, see Perrimon 1994), the existing data support the view that dominant-negative Wnts function extracellularly as dominant-negative ligands. It is possible that the dominant-negative Wnts block activation of a putative Wnt receptor by binding to extracellular factors normally involved in presenting endogenous Wnt ligands to a receptor, by binding but not activating a receptor, or by forming a nonfunctional heterodimer with wild-type Wnts (see also Burrus and McMahon 1995). Whichever mechanism proves correct, we expect that dominant-negative Wnts will be generally useful in studying the mechanism and functions of Wnt signaling in a range of tissues and organisms.

\section{Materials and methods}

Construction of dnXwnt- 8 and dnWnt-1

PCR primers designed to truncate $X w n t-8$ DNA after the position encoding the peptide sequence SPDYC were synthesized. All primer sequences are given in the $5^{\prime} \rightarrow 3^{\prime}$ orientation: forward, GCGAATTCCTTCATCATGCAAAACAC and reverse, GCGAATTCTCAGCAATAATCGGGAGAGTC. The primers for the equivalent truncation in Wnt-1 were forward, CCGGAATTCCAGGCCATGGGGCTC and reverse, CCGGAATTCTCAGCAGAAGTTGGGCGATTTC. PCR was performed according to manufacturers' recommendations using AmpliTaq (Perkin-Elmer Cetus) or DeepVent (NEB) polymerases from plasmids encoding Xwnt-8 cDNA (Christian et al. 1991) or Wnt-1 cDNA (McMahon and Moon 1989). Note that each primer contains an EcoRI site at its $5^{\prime}$ end, which enabled us to clone the PCR-amplified products into the EcoRI site of the $\mathrm{CS} 2+$ expression vector (gift from D. Turner, Fred Hutchinson Cancer Research Center, Seattle, WA). The resulting constructs $d n X w n t-8$ and $d n W n t-1$ were sequenced and found not to contain any point mutations. Each deletion construct was in vitro 
translated and yielded proteins of the expected mobility on SDS gels (data not shown).

\section{Embryo methods}

Xenopus laevis (Daudin) eggs were collected and fertilized, and the embryos handled, cultured, and injected with RNA or plasmid as described previously (Nieuwkoop and Faber 1967; Moon and Christian 1989; Christian and Moon 1993). Capped RNAs were prepared with the commercially available Message Machine kit (Ambion) using linearized plasmid DNA as templates, which encode $\Delta \beta$-catenin (a truncated form of $\beta$-catenin; Yost et al. 1996); BVg1 (Kessler and Melton 1995); Xwnt-8 (Christian et al. 1991); Xwnt-8myc, a human myc epitope-tagged Xwnt-8 (Christian and Moon 1993); Wnt-1 (McMahon and Moon 1989); Xwnt-3A (Wolda et al. 1993); dnXwnt-8 (see above); dnWnt-1 (see above); and lacZ (CS + nßgal; a gift from D. Turner), and injected in amounts indicated. Control RNAs used were either

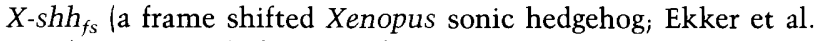
1995) or Wnt-1 $1_{\text {fs }}$ (a frame-shifted Wnt-1 derivative; J.D. Brown, unpubl.). Where indicated, embryos and explants were processed for histology as described (Christian and Moon 1993).

\section{RT-PCR assays}

RT-PCR analyses were carried out as described previously /Cui et al. 1995). All primer sequences are given in the $5^{\prime} \rightarrow 3^{\prime}$ orientation: $X p o$ primers: forward, CACTTAGGGATTGGTCTCAGGAGTC and reverse, TGAGGGAGGGCTATGGTCTAGG; Evx1 primers: forward, ACCTATATGATGAGCCACGCAG and reverse, GCCGTTGGTTGAGGTACTAAGAC. Other primers were published previously [Histone $\mathrm{H} 4$ (Niehrs et al. 1994; Cui et al. 1995) and gsc (Hemmati Brivanlou et al. 1994)].

\section{RNA and protein localization}

In situ hybridization analysis was performed according to a standard protocol (Harland 1991) using probes for gsc (Cho et al. 1991), noggin (Smith and Harland 1992), Xnr3 (Smith et al. 1995), Xpo (Sato and Sargent 1991), and XMyoDa (Frank and Harland 1991). For the X-gal, myc antibody double staining, embryos were fixed in $3.7 \%$ formaldehyde in PBS for $45 \mathrm{~min}$, then incubated in X-gal reaction mixture (Sanes et al. 1986) for $\sim 1 \mathrm{hr}$, washed in PBS, and then taken through the antibody protocol described below. For the antibody staining, embryos were incubated with the muscle-specific 12/101 monoclonal antibody (Kintner and Broockes 1984) or the anti-myc monoclonal antibody $9 \mathrm{E} 10$ and processed for whole-mount immunohistochemistry as described previously (Moon and Christian 1989).

\section{Acknowledgments}

We owe a great debt to Alfonso Martinez Arias for discussions on how Wnt proteins function, for communicating results before publication, and for sending a plasmid encoding Dwnt- ${ }^{\mathrm{S} 84}$. We are grateful to members of the Moon and Kimelman labs for discussion and advice, especially to Jennifer Schmidt and Sarah Pierce for supplying molecular reagents, to Cheng-Jung Lai for excellent technical advice, and to David Kimelman for comments on the manuscript. Thanks are due to Chao-Min Amy Chen, Ralph Rupp, William Smith, and David Turner for gifts of molecular reagents and to Minh Vo Sum for helping with the figures. S.H. acknowledges support by the European Molecular Biology Organization (ALTF 706-1994), J.D.B. is supported by a
Public Health Service grant (NIH2T32HDO7183-16), and R.T.M. is an investigator of the Howard Hughes Medical Institute. This research was supported by a grant from the National Institutes of Health (HD27525).

The publication costs of this article were defrayed in part by payment of page charges. This article must therefore be hereby marked "advertisement" in accordance with 18 USC section 1734 solely to indicate this fact.

\section{References}

Amaya, E., P.A. Stein, T.J. Musci, and M.W. Kirschner. 1993. FGF signalling in the early specification of mesoderm in $\mathrm{Xe}$ nopus. Development 118: 477-487.

Baylies, M.K., A. Martinez Arias, and M. Bate. 1995. wingless is required for the formation of a subset of muscle founder cells during Drosophila embryogenesis. Development 121: 38293837.

Bejsovec, A. and E. Wieschaus. 1995. Signaling activities of the Drosophila wingless gene are separately mutable and appear to be transduced at the cell surface. Genetics 139: 309-320.

Benezra, R., R.L. Davis, D. Lockshon, D.L. Turner, and H. Weintraub. 1990. The protein Id: A negative regulator of helixloop-helix DNA binding proteins. Cell 61: 49-59.

Burrus, L.W. and A.P. McMahon. 1995. Biochemical analysis of murine Wnt proteins reveals both shared and distinct properties. Exp. Cell Res. 220: 363-373.

Cho, K.W., B. Blumberg, H. Steinbeisser, and E.M. De Robertis. 1991. Molecular nature of Spemann's organizer: The role of the Xenopus homeobox gene goosecoid. Cell 67: 1111-1120.

Christian, J.L. and R.T. Moon. 1993. Interactions between $X w n t-8$ and Spemann organizer signaling pathways generate dorsoventral pattern in the embryonic mesoderm of Xenopus. Genes \& Dev. 7: 13-28.

Christian, J.L., J.A. McMahon, A.P. McMahon, and R.T. Moon. 1991. Xwnt-8, a Xenopus Wnt-1/int-1-related gene responsive to mesoderm-inducing growth factors, may play a role in ventral mesodermal patterning during embryogenesis. Development 111: 1045-1055.

Couso, J.P. and A. Martinez Arias. 1994. Notch is required for wingless signaling in the epidermis of Drosophila. Cell 79: 259-272.

Cui, Y., J.D. Brown, R.T. Moon, and J.L. Christian. 1995. Xwnt8b: A maternally expressed Xenopus Wnt gene with a potential role in establishing the dorsoventral axis. Development 121: $2177-2186$.

Cunliffe, V. and J.C. Smith. 1994. Specification of mesodermal pattern in Xenopus laevis by interactions between Brachyury, noggin and Xwnt-8. EMBO J. 13: 349-359.

Dale, L., G. Howes, B.M. Price, and J.C. Smith. 1992. Bone morphogenetic protein 4: A ventralizing factor in early Xenopus development. Development 115: 573-585.

Du, S.J., S.M. Purcell, J.L. Christian, L.L. McGrew, and R.T. Moon. 1995. Identification of distinct classes and functional domains of Wnts through expression of wild-type and chimeric proteins in Xenopus embryos. Mol. Cell. Biol. 15: 2625-2634.

Ekker, S.C., L.L. McGrew, C.J. Lai, J.J. Lee, D.P. von Kessler, R.T. Moon, and P.A. Beachy. 1995. Distinct expression and shared activities of members of the hedgehog gene family of Xenopus laevis. Development 121: 2337-2347.

Fainsod, A., H. Steinbeisser, and E.M. De Robertis. 1994. On the function of $B M P-4$ in patterning the marginal zone of the Xenopus embryo. EMBO J. 13: 5015-5025. 
Fan, C.M. and M. Tessier Lavigne. 1994. Patterning of mammalian somites by surface ectoderm and notochord: Evidence for sclerotome induction by a hedgehog homolog. Cell 79: $1175-1186$.

Frank, D. and R.M. Harland. 1991. Transient expression of $X M y o D$ in non-somitic mesoderm of Xenopus gastrulae. $D e-$ velopment 113: 1387-1393.

Graff, J.M., R.S. Thies, J.J. Song, A.J. Celeste, and D.A. Melton. 1994. Studies with a Xenopus BMP receptor suggest that ventral mesoderm-inducing signals override dorsal signals in vivo. Cell 79: 169-179.

Hammerschmidt, M., M.J. Bitgood, and A.P. McMahon. 1996. Protein kinase $\mathrm{A}$ is a common negative regulator of Hedgehog signaling in the vertebrate embryo. Genes \& Dev. 10: $647-658$.

Harland, R.M. 1991. In situ hybridization: An improved whole mount method for Xenopus embryos. In Methods in cell biology (ed. B.K. Kay and H.J. Peng), pp. 685-695. Academic Press, Inc., San Diego, CA.

Harvey, R.P. 1990. The Xenopus MyoD gene: An unlocalised maternal mRNA predates lineage-restricted expression in the early embryo. Development 108: 669-680.

Heasman, J., A. Crawford, K. Goldstone, P. Garner Hamrick, B. Gumbiner, P. McCrea, C. Kintner, C.Y. Noro, and C. Wylie. 1994. Overexpression of cadherins and underexpression of beta-catenin inhibit dorsal mesoderm induction in early $\mathrm{Xe}$ nopus embryos. Cell 79: 791-803.

Hemmati Brivanlou, A., O.G. Kelly, and D.A. Melton. 1994. Follistatin, an antagonist of activin, is expressed in the Spemann organizer and displays direct neuralizing activity. Cell 77: 283-295.

Hopwood, N.D. and J.B. Gurdon. 1990. Activation of muscle genes without myogenesis by ectopic expression of $M y O D$ in frog embryo cells. Nature 347: 197-200.

Hopwood, N.D., A. Pluck, and J.B. Gurdon 1989. MyoD expression in the forming somites is an early response to mesoderm induction in Xenopus embryos. EMBO J. 8: 34093417.

Hume, C.R. and J. Dodd. 1993. Cwnt-8C: A novel Wnt gene with a potential role in primitive streak formation and hindbrain organization. Development 119: 1147-1160.

Kelly, G.M., P. Greenstein, D.F. Erezyilmaz, and R.T. Moon. 1995. Zebrafish wnt 8 and wnt $8 b$ share a common activity but are involved in distinct developmental pathways. Development 121: 1787-1799.

Kessler, D.S. and D.A. Melton. 1995. Induction of dorsal mesoderm by soluble, mature $\mathrm{Vg} 1$ protein. Development 121: $2155-2164$

Kintner, C. and J.P. Broockes 1984. Monoclonal antibodies to the cells of regenerating limb. J. Embryol. Exp. Morph. 89: 37-55.

McGrew, L.L., C.J. Lai, and R.T. Moon. 1995. Specification of the anteroposterior neural axis through synergistic interaction of the Wnt signaling cascade with noggin and follistatin. Dev. Biol. 172: 337-342.

McMahon, A.P. and R.T. Moon 1989. Ectopic expression of the proto-oncogene int-1 in Xenopus embryos leads to duplication of the embryonic axis. Cell 58: 1075-1084.

Moon, R.T. and J.L. Christian 1989. Microinjection and expression of synthetic mRNAs in Xenopus embryos. Technique 1: 76-89.

Münsterberg, A.E., J. Kitajewski, D.A. Bumcrot, A.P. McMahon, and A.B. Lassar. 1995. Combinatorial signaling by Sonic hedgehog and Wnt family members induces myogenic bHLH gene expression in the somite. Genes \& Dev. 9: 2911-2922.

Murre, C., P.S. McCaw, and D. Baltimore 1989. A new DNA binding and dimerization motif in immunoglobulin enhancer binding, daughterless, MyoD, and myc proteins. Cell 56: $777-783$.

Niehrs, C., H. Steinbeisser, and E.M. De Robertis. 1994. Mesodermal patterning by a gradient of the vertebrate homeobox gene goosecoid. Science 263: 817-820.

Nieuwkoop, P.D. 1969. The formation of the mesoderm in urodelean amphibians I. The induction by the endoderm. Wilhelm Roux's Arch. Entwicklungsmech. Org. 162: 341373.

Nieuwkoop, P.D. and J. Faber. 1967. Normal table of Xenopus laevis. North-Holland Publishing Company, Amsterdam, The Netherlands.

Nusse, R. and H.E. Varmus 1982. Many tumors induced by the mouse mammary tumor virus contain a provirus integrated in the same region of the host genome. Cell 31: 99-109.

Parr, B.A. and A.P. McMahon. 1994. Wnt genes and vertebrate development. Curr. Opin. Genet. Dev. 4: 523-528.

Perrimon, N. 1994. The genetic basis of patterned baldness in Drosophila. Cell 76: 781-784.

Rudnicki, M.A., T. Braun, S. Hinuma, and R. Jaenisch. 1992. Inactivation of $M y O D$ in mice leads to up-regulation of the myogenic HLH gene $M y f-5$ and results in apparently normal muscle development. Cell 71: 383-390.

Ruiz i Altaba, A. and D.A. Melton 1989. Bimodal and graded expression of the Xenopus homeobox gene Xhox3 during embryonic development. Development 106: 173-183.

Rupp, R.A. and H. Weintraub. 1991. Ubiquitous $M y o D$ transcription at the midblastula transition precedes inductiondependent $M y o D$ expression in presumptive mesoderm of $X$. laevis. Cell 65: 927-937.

Sanes, J.R., J.L. Rubenstein, and J.F. Nicolas. 1986. Use of a recombinant retrovirus to study post-implantation cell lineage in mouse embryos. EMBO I. 5: 3133-3142.

Sato, S.M. and T.D. Sargent. 1991. Localized and inducible expression of Xenopus-posterior (Xpo), a novel gene active in early frog embryos, encoding a protein with a "CCHC" finger domain. Development 112: 747-753.

Scales, J.B., E.N. Olson, and M. Perry. 1990. Two distinct Xenopus genes with homology to $M y o D 1$ are expressed before somite formation in early embryogenesis. Mol. Cell. Biol. 10: 1516-1524.

Schmidt, J.E., A. Suzuki, N. Ueno, and D. Kimelman. 1995. Localized BMP-4 mediates dorsal/ventral patterning in the early Xenopus embryo. Dev. Biol. 169: 37-50.

Smith, W.C. and R.M. Harland. 1991. Injected Xwnt-8 acts early in Xenopus embryos to promote formation of a vegetal dorsalizing center. Cell 67: 753-766.

- 1992. Expression cloning of noggin, a new dorsalizing factor localized to the Spemann organizer in Xenopus embryos. Cell 70: 829-840.

Smith, W.C., A.K. Knecht, M. Wu, and R.M. Harland. 1993. Secreted noggin protein mimics the Spemann organizer in dorsalizing Xenopus mesoderm. Nature 361: 547-549.

Smith, W.C., R. McKendry, S. Ribisi Jr., and R.M. Harland. 1995. A nodal-related gene defines a physical and functional domain within the Spemann organizer. Cell 82: 37-46.

Steinbeisser, H., A. Fainsod, C. Niehrs, Y. Sasai, and E.M. De Robertis. 1995. The role of gsc and BMP-4 in dorsal-ventral patterning of the marginal zone in Xenopus: A loss-of-function study using antisense RNA. EMBO I. 14: 5230-5243.

Stern, H.M., A.M.C. Brown, and S.D. Hauschka. 1995. Myogenesis in paraxial mesoderm: Preferential induction by dorsal neural tube and by cells expression Wnt-1. Development 121: 3675-3686.

Stewart, R.M. and J.C. Gerhart. 1990. The anterior extent of 
dorsal development of the Xenopus embryonic axis depends on the quantity of organizer in the late blastula. Development 109: 363-372.

Torres, M.A., J.A. Yang-Snyder, S.M. Purcell, A.A. DeMarais, L.L. McGrew, and R.T. Moon. 1996. Activities of the Wnt-1 class of secreted signaling factors are antagonized by the Wnt-5A class and by a dominant negative cadherin in early Xenopus development. J. Cell Biol. 133: 1123-1137.

Weinberg, E.S., M.L. Allende, C.S. Kelly, A. Abdelhamid, T. Murakami, P. Andermann, O.G. Duerre, D.J. Grunwald, and B. Riggleman. 1996. Developmental regulation of zebrafish myoD in wild-type, notail and spadetail embryos. Development 122: 271-280.

Wolda, S.L., C.J. Moody, and R.T. Moon. 1993. Overlapping expression of Xwnt-3A and Xwnt-1 in neural tissue of Xenopus laevis embryos. Dev. Biol. 155: 46-57.

Yost, C., M. Torres, J.R. Miller, E. Huang, and D. Kimelman. 1996. The axis-inducing activity, stability, and subcellular distribution of $\beta$-catenin is regulated in Xenopus embryos by glycogen synthase kinase 3. Genes \& Dev. 10: 1443-1454. 


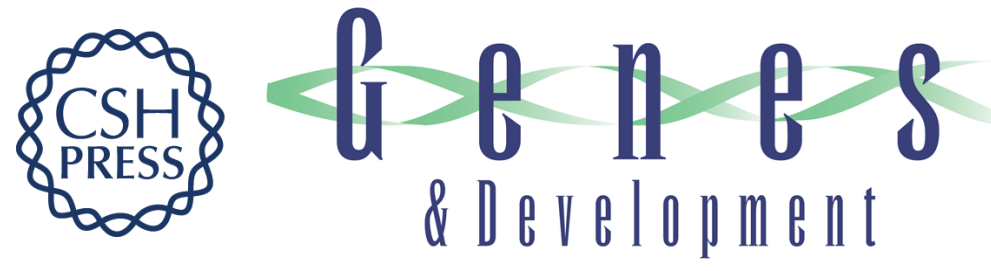

\section{Expression of a dominant-negative Wnt blocks induction of MyoD in Xenopus embryos.}

S Hoppler, J D Brown and R T Moon

Genes Dev. 1996, 10:

Access the most recent version at doi:10.1101/gad.10.21.2805

References This article cites 56 articles, 24 of which can be accessed free at:

http://genesdev.cshlp.org/content/10/21/2805.full.html\#ref-list-1

License

Email Alerting

Service

Receive free email alerts when new articles cite this article - sign up in the box at the top right corner of the article or click here.

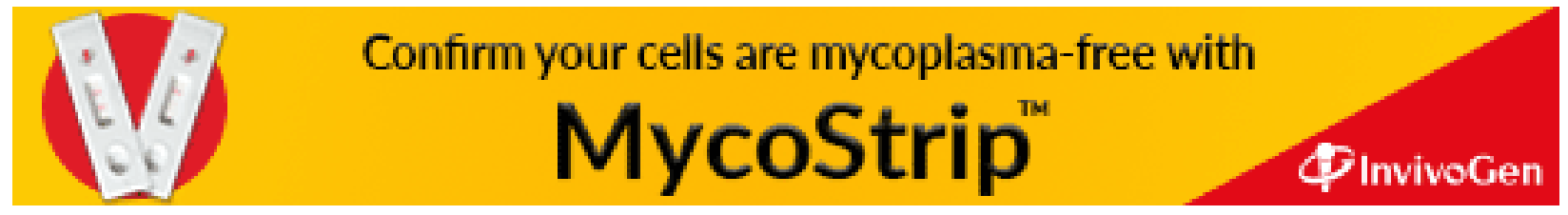

